\title{
Towards Designing a Rabbani Education for Ummah: An Overview on Some Major Issues in Indonesia
}

\author{
M Naim Madjid ${ }^{1}$ \\ \{naimmadjid@umy.ac.id ${ }^{1}$ \} \\ Universitas Muhammadiyah Yogyakarta ${ }^{1}$
}

\begin{abstract}
Education is a fundamental aspect in building a civilization. The human role as actor of education will determine development and lack of nation. Education system becomes an important indicator in shaping people educated and superior. The aim of this study is to highlight some major issues in Indonesia such as social justice, politic, economy, and education that built by incorrect concept of knowledge. Rabbani education is one model that emphasizes religious values to reach the peak of civilization as the best nation (Ummah Wasatan). Rabbani is solution for Ummah, particularly in dealing with major social problems such as corruption, violation of human right, scandal and poverty. This paper used qualitative method by using a descriptive approach to obtain the true data. The most important result is Rabbani education can be implemented in the curricula of Indonesia's education as the main spirit in performing a comprehensive, progressive and affective education.
\end{abstract}

Keywords: Designing; Rabbani Education; Ummah Wasatan; Major Issues; Comprehensive; Progressive and Affective.

\section{INTRODUCTION}

Indonesia was known as the world's largest island country, with more than seventeen thousand islands. With over 261 million people, it is the world's 4th most populous country as well as the most populous Muslim-majority country. Before 1949, it was a colonial territory, the Netherlands East Indies, Borneo and Timor are partly Indonesian territory. The largest islands include Sumatra and Celebes, but Java outweighs all others politically and economically. All suffered from rebellions and fighting with Dutch troops after the proclamation of formal independence, in 1945. The indigenous people fall into three groups, distinct both culturally and linguistically, though all are Muslim; Javanese live in the eastern two-thirds of the island, Sudanese to the west, and Madurese in the north-east. Additionally they are about one to two million Chinese, prominent as traders and industrialists, settled in the towns. A substantial number of Hadramaut Arabs are traders and Muslim teachers. It obviously indicates that the laying of a cornerstone of education took place by Arab traders [1].

Development of information and technology over centuries has given a significant influence for Indonesia's education system. In spite of the fact that Indonesia's expenditure on science and technology is relatively low, at less than $0.1 \%$ of GDP (2017), and the result says that it is not considered as a leading country on the subject, but Indonesia is among the largest countries by number of Internet users, with estimation 88 million users in 2016 where the penetration was begun in the early 1990s.. It shows us that media freedom, communications 
system and rapid of technology increased considerably in the sixteen years. What the most important to give highlights to this quickness is technology has changed the manually education system to digitally form which led to the complexity of method, but try to construct the human's thinking of way instantly that never expected. It emphasizes to the outcome and the product of education, and pay no attention to the process and the solving problem. This actually is a big problem in our education system. Islam as we know that opens widely the accessibility of knowledge by integrated system between revelation and science.

Rabbani education is one of the outstanding terms the writer would like to disclosure its basic principles, main objectives and prominent approaches for our academic discourse today. It is believed that this discussion will give a new contribution in the hope of good understanding and implementation of concept which is beneficial for all generation.

\section{MEANING AND CONCEPT}

The Arabic word, Rabbānī is derived from three letters: $\mathrm{Ra}, \mathrm{Ba}, \mathrm{Ba}$; and $a l-R a b b$ refers to the Allah as the Lord and the Owner of everything. His unity of lordship includes all creation. Al- Rāghib al- Asfahāni (425 C.E) said: the original meaning of $a l-R a b b$ is $a l$ Tarbiyah (education), make something grow by time to time towards the limit of perfection [2]. Ibn Manzūr (1311 C.E.) mentioned: Literally al- Rabb refers to: al-Mālik (the Owner), alSayyid (the Master), al-Mudabbir (the Arranger), al-Murabbi (the Keeper), al- Qayyim, and al- Mun 'im (the Giver of blessing). As for the Ibn al- Anbāri came to divide al-Rabb into three types: al- Mālik, al- Sayyid al- Mutā', and al- Muslih (who do righteous deeds). While the plural form of $a l-R a b b$ is $A r b \bar{a} b$ and $R u b \bar{u} b$ [3].

According to the interpretation of scholars in the book of Fakhr al- Dīn al- Rāzi (1210 C.E.) as known as Mafâtīh al-Ghayb (Keys to the Unseen), and later nicknamed Tafsīr alKabīr (The Great Commentary), al-Rabbān̄ leads to the several meanings: Sibawayh (796 C.E.) said: It is attributed to God which means who have knowledge about Him, and who is steady on his obedience to Him. Addition both letters Alif and Nun indicates to an exaggeration of expression (al- Mubālaghah, is make something seem larger or more important than it really is), or perfection of character such as Sya'räniyyun (who has long hair), Lahyāniyyun (long bearded man) and Raqabāniyyun (stubborn). Based on the alMubarrad's opinion: al- Rabbāniyyūn is a plural form meant: They are the lords of knowledge, and Rabbāniyun is a person who keep knowledge and keep mankind; who teach the people, educate them, do righteous deeds for them, and give great concern to their matters. Ibn Zaid mentioned: al-Rabbāniyyūn are the guardians of Ummah and the Scholars [4].

Actually, the word Rabbāniyyūn is listed in three verses of Quran:

Firstly, in the Sūrat Āli 'Imrān (The Family of Imran): 79: "On the contrary (he would say): "Be you Rabbāniyyūn (learned men of religion who practice what they know and also preach others), because you are teaching the Book, and you are studying it". Means, the Messenger (pbuh) recommends the people to be Rabbāniyyūn. Ibn 'Abbās, Abu Razīn and several others said that Rabbāniyyūn means, "Wise, learned, and forbearing". Secondly, in the Sūrat al- Māidah (The Table Spread With Food): 44: "And the rabbis and the priests (too judged for the Jews by the Taurāh (Torah) after those Prophets", wherein Rabbāniyyūn refers to the worshippers who are learned and religious, and Ahbār refers to the scholars. Thirdly, in the Sūrat al- Māidah (The Table Spread With Food): 63: "Why do not the Rabbis and the religious learned men forbid them from uttering sinful words and from eating illegal things. 
Evil indeed is that which they have been performing". The Rabbanniyyūn are the scholars who are in positions of authority, while the Ahbār are the regular scholars [5].

As for the verb form rabba yarubbu was stated in a short Hadis: (laka ni'matun tarubbuhā), it means: "For you a blessing, so keep it and take care of it", as the Man educates and keeps his son.

In conclusion, Rabbān̄̄ education has brilliant and outstanding characteristics which attempt to conduct the people to the holistic progressive, and affective education. This special attribute indicates strongly that education must be seen holistically and must be performed perfectly. The holistic view means education must to reach all levels of society in the city and village, must able to absord Rabbānī principles: belongings, keep, nurture, educate, supervise, protect, provide, and control, as contained in the second verse of al- Fātihah: "All praise and thanks are Allah's the Lord of the "Alamin (mankind, jinn and all that exists)". Lord: The actual word used in the Qur'ān is Rabb. There is no proper equivalent for Rabb in English language. It means the One and the Only Lord for all the universe, its Creator, Owner, Organizer, Provider, Master, Planner, Sustainer, Cherisher, and Giver of security. All occurrences of "Lord in the interpretation of the meanings of the Noble Qur'an actually mean Rabb and should be understood as such.

Education also must move forward and continuously about how to develop knowledge and curriculum based on the benefit of Ummah. While the perfect performance leads to the integrated system by focusing on the three components: intellectual question (hard-skill), emotional question (soft-skill), and spiritual question (good awareness and practice), and the most important is that education has to resolve the people's problems completely and fairly, and it able to escape them from the shadow of materialism, hedonism, and capitalism.

Based on the sacred purposes, the main direction of Rabbani education is to be Ummah Wasatan (the community of the middle way). Sayyid Qutb - he is an Egyptian author, a great thinker, educator, Islamic theorist, poet, and a leading member of the Egyptian Muslim Brotherhood (Ikhwān al- Muslmīn) in the 1950s and 1960s, and he died on 29th August 1966 as a Martyr of Islām - commented clearly the meaning of Ummah Wasatan which actually is a specific embodiment of the vicegerent on earth. He said in his book (In the Shade of the Quran): The community of the middle way: The Muslim community is balanced in the sense that it is not rigid or dogmatic. It holds fast to its ideals and traditions, and to the sources of religion and way of life, while fostering change and progress in all fields. Its framework is balance and moderation. It is a society raised on learning, education and rich cultural and social traditions [6].

In the Indonesia context, the term Ummah Wasatan can be interpreted in Indonesia languange as "sebuah masyarakat Islam yang sebenar-benarnya" with a reason that Ummah Wasatan walk on a balance of life, they enjoin what is right and forbid what is wrong, so they are the real Islamic community. This term was mentioned by Muhammadiyah Organization (Persyarikatan Muhammadiyah) in its Article of Association (in Article III: Purpose, Objectives and Activities, 2005) that Muhammadiyah's purpose and objective is uphold and respect the dignity of Islam and to develop a real Islamic community [7]. In the contemporary Indonesian context, Muhammadiyah identifies itself with moderate Islam, adopting a position between extreme-liberalism and extreme-Islamism, as well as in the politic has adopted a neutral stance towards all political parties in Indonesia, refusing affiliate with any of them, as it did on several occasions [8].

The concept of moderate Islam is often seen to be equivalent with the Arabic term alDīn al- Wasat in the Quran (2: 143). There is a coherency or a same linkage between both Ummah Wasatan and real Islamic community, or al- Dīn al- Wasat and moderate Islam. In 
other word, Rabbani education system and Muhammadiyah organization both has a same direction is to develop a community of the middle way that move forward in balance and moderation based on the Islamic values and the Lord's principles.

\subsection{Lordship Principles}

Before presenting the Islamic view on this section, a prolegomenon about the cornerstone of the entire faith of Islam will be started by giving the meaning of the Tawhīd as the first pillar of Islam. It is strongest connected with the belief in God, because the unity of God must be put in the view of belief.

Tawhīd is the acceptance and firm belief in only one God, who is one Lord, one Creator, one Owner, one Sustainer, etc. When something is made one it is called a "unity". However, Islamically Tawhìd means to believe that Allah is the one and only God in all of the things that we do to please Him. For example, prayer should only be to Allah, sacrifice should only be done in Allah's name, charity should only be given for Allah's pleasure and Jihäd should only be fought for the sake of Allah's religion. Here, it is called Tawhīd al-Ulühiyyah (the Oneness of God). In the meantime, Tawhìd al-Rubübiyyah (the Unity of Lordship) means that we accept Allah as being the only real power in the Universe. He caused all things to exist when there was nothing; thus, He is called al-Khäliq, the Creator. He is the one who gave all things the power to grow, to move and to change, so He is called $a l-R a b b$. Nothing happens except what He allows to happen; thus He is called al-Mālik, the Owner of the Universe [9].

As was mentioned that the principles of the Lordship in Islam are contained in the first Surah as the opening of holy Book (al- Fātihah). The surah obviously mentioned word Rabb in the second verse which linguistically - as we sataed - means the owner who has full authority over his property. While 'Álamin is plural for 'Alam, which encompasses everything in existence except Allah. The word 'Alam is itself a plural word, having no singular form. alFarra and Abu 'Ubayd said: 'Ālam includes all that has a mind, Jinns, mankind, the angels and the devils, but not the animal". Also, Zayd bin Aslam and Abu Muhaysin said: "'Alam includes all that Allah has created with a soul". Further, Qatādah said about Rabb al- 'Älamīn (the Lord of the 'Alaminn): "every type of creation is an "Alam". Al- Zajjaj also commented: “ 'Álam encompasses everything that Allah created, in this life and in the Hereafter". While alQurtubi clarified al- Zajjāj's statement. Similarly when Moses (Musa) said to Pharaoh (Fir'awn) in the Sūrat al- Syu'arā': 24:

"The Lord of the heavens and the earth, and all that is between them, if you seek to be convinced with certainly".

In the third verse, al-Rahmān (the Most Gracious) and al-Rahīm (the Most Merciful) the Qur'an mentions both at the second time - with the first at the beginning - means the Rabb contains a warning while both Allah's names encourage. It also can be interpreted that Allah is the Owner of mercy in both worlds. And the next verse says that Allah is the Owner or the King of the Day of Recompense. It explains that no one except Him will be able to claim ownership of anything whatsoever on that Day, and no one will be allowed to speak without His permission. Everything is under His authority. The fifth verse states clearly about the Oneness and the Lordship of Allah that we (are the Muslim and the believers) worship You alone and none else and rely on You alone and none else. This is the perfect form of obedience and the entire religion is implied by these two ideas. The first part is a declaration of innocence from Shirk (polytheism), while the second negates having any power or strength, displaying the recognition that all affairs are controlled by Allah alone. This combination also 
can be found in the CXII Surah (al-Ikhlās or the Purity) and in the Surah al- Baqarah: 255). The proofs of His Lordship were stated specifically in the 164th of al- Baqarah. These evidences show us that the principles of the Oneness of the Lordship of Allah flow into values of the ownership, the authority and the safeguarding. The first one means full coverage of everything which we call it as a totality. The second one means direct controlling which leads to the great influence. And the third one means full attention which conducts to the balance of continuity.

\section{OVERVIEW OF SOME MAJOR ISSUES}

The fact is that the Indonesia's spirit of struggle has long been etched in the Constitution 1945, which describe the nation's goals clearly, include the education purpose to educate the life of the people based on perpetual peace and social justice as the main destination. Meanwhile, the concept of developing country was listed philosophically in the lyrics of the national anthem, Indonesia Raya, for example, Bangunlah jiwanya, bangulah badannya (build its soul, build its body). The same is true with regard to recognize the Oneness of God, the justice, piety and harmony values of people, are contained in the pillars of the Republic of Indonesia. It indicates that Indonesia actually has adopted the Lordship principles and Islamic values. This is a point of view theoretically.

In view of achievement of science and technology advancement, Indonesia has reached the peak by spreading information and internet usage widely. Many educational institutions were established, and research projects have dominated Indonesia's education world in all fields. But there some crucial corners escaped from the Government's attention and the touching of educators. These problems are the mistake of point of view of knowledge, the loss of knowledge culture, and the unbalance between understanding and act. However, this development has opened a freedom by out of hand, and people were really lulled by its jewelry until they did not see those problems clearly. Therefore, we need a correct model in solving the problems and - at the same time - formatting the integrity of nation in the frame of virtue.

The problems can be highlighted by some major issues as follows:

\subsection{Social Justice}

Indonesia expressed succinctly in the fifth principle of its ideology, Pancasila, that social justice for all the Indonesian people. It is an unexceptional commitment that showed Indonesia - since long time ago - has adopted Islamic values which put all people in the similarity of rights and tasks. This principle leads to the convergent several meanings: balance, harmony, stability and equivalency or equality for each citizen to obtain fair life and comfortable. In fact, Indonesian population living in poverty per September 2018 was 25.67 million people, 0.28 million lower compared to that of March 2018, and 0.91 million lower compared to that of September 2017. It was stated clearly by Suhariyanto, Head of the Central Statistics Agency (BPS), on 15th January 2019, in Jakarta [10]. Ironically, this evidence disturbs our minds when we see around of us many beggars and homeless people out of government controlling and supervision. 


\subsection{Politic Atmosphere}

The politic is a fundamental aspect in the affairs of state. It conducts people to the good system or not. The politic of Indonesia has walked on the fluctuated rhythm in the last five years. In other word, politic of Indonesia is unpredictable, depends on the several factors such as economy, education, socio-culture and religion. The economy factor is the main reason which makes the politic confused and bring the people misguided. The money politic for example became a crucial problem in the post-New Order regime (2014), particularly in welcoming the long election round. Therefore, politic education is thus important to resolve the problems and to unite the people's view on healthy political system, instead of making education issue as a lure for the victory of election. Meantime, dynamic socio-cultural development gives more influence to the color of Indonesia's politic. In this digital era, old and new issues on the politic are disclosed through social media communication and widespread without filtration unfortunately. In consequence, the political narration becomes uncontrolled and out of rule. This is a rapid erosion of cultural values in dispute of the lust (alHawā' wal al- Nafs) and mind (al- 'Aql). In the last range, religion issue has built community paradigm that the leader's background of religiosity is one of the political assessments.

\subsection{Economic Growth}

Indonesia is the largest economy in South East Asia. Industry and services sides and agriculture have contributed positively to the GDP (Gross Domestic Product) growth. Despite the data account Indonesia's annual economic growth eased to 5.07 percent in the first quarter of 2019 from 5.18 percent in the previous three-month period and below market consensus of 5.18 percent. GDP Annual Growth Rate in Indonesia averaged 5.28 percent from 2000 until 2019 , reaching an all-time high of 7.16 percent in the fourth quarter of 2004 and a record low of 1.56 percent in the fourth quarter of 2001 [11].

Be that as it may, Indonesia's economy helped reduce poverty to a record low of 9.7 percent in September 2018, as it was mentioned by Rodrigo A. Chaves, World Bank Country Director for Indonesia and Timor-Leste in press release on July 1st 2019 [12].

But the fact is the economic growth does not reach all segments of the population yet. The development has worked at the material construction like infrastructure and private investments, without emphasize on the build of human resources steadily. Teaching the farmers how to product and use artificial fertilizer is more important than providing their needs. It is shown by loss of independence of many productive economic programs in the Village and there is practically no guidance system of healthy business economy. Therefore, prudent economic education is most important to be implanted to people to avoid a perennial disease which perched on the heart of urban and rural communities, poverty.

\subsection{Education System}

Education sector is one of the sectors which contribute to the human development. HDI (Human Development Index) is used to measure life expectancy, literacy, education, and standard of living for all countries around the world. The human development in education is more related to the education system used of each country. Education system - as known as curriculum - in Indonesia is changeable within several times, from the learning method by 
active student (CBSA), curriculum based on the competence (KBK), curriculum at the unit of education level (KTSP) until to the 2013 curriculum. This changing was full of the controlling and domain of the government. The problem looks at the integration of subjects in thematic lesson of 2013 curriculum which does not conform to the competence of pupil and teachers yet. As the result, education objectives did not work optimally.

On the other hand, the problem comes from the private schools which offer higher education fee, and the furthest condition as if some of them are money oriented. It is absolutely caused by the lack of religion understanding (Fahm al- Dīn) and attitude values (alQiyām al- Sulūkiyyah) in the nation life.

\section{RESULT AND DISCUSSION}

\subsection{The Nature of Science}

Islam is a perfect religion, perfecting religion or pre-existing teachings and becoming a blessing for all nature (rahmatan lil 'Ālamīn). Islam has placed humankind to a highest level as one perfect creation by 'Aql (brain). This mind will bring every human who has faith to be a civilized, knowledgeable and devoted person to Him.

As we have seen that the coming of Islam as rahmatan lil 'Ālamīn has ushered mankind from the darkness to a bright light, namely from the ignorance to the salvation of the afterlife. Surely the Qur'an and the Sunnah of the Prophet are the main grips in achieving the salvation of the Hereafter. As the Prophet said:

From Abu Hurairah r.a., from the Prophet (pbuh) said: "I leave you two cases, you will not be lost as long as you hold fast to both, namely the book of Allah (the holy Qoran) and the Sunnah of His Messenger."

The holy Qur'an stated clearly about the importance of the role of 'aql is to elevate the man to the levels of virtue. 'Aql was created for humankind to think, know himself, his Creator and the nature. In education, activities like study, research and understanding of knowledge can be performed perfectly by using 'aql properly, is how to lean our mind (read: 'aql) always to the Lord the Merciful.

\subsection{Qur'anic Education Method}

The revelation of prophet (pbuh) really has gave us important lessons in understanding the true of knowledge. The first revelation (Qur'an, 96: 1-5) signifies the first step for the mankind to know himself and Universe by elevating his Creator. The second revelation (Qur'an, 74: 1-7) encourages us to do 'Da'wah (invocations) to our selves, family and people, and at the same time it motivates us to maintain in our righteous pursuits (al- Istiqāmah) or in performing our duty to Allah. While the third one (Qur'an, 5:3) talks about the perfection of religion (al- Islām) and God's favour to the prophet (pbuh) that each someone who admitted himself as a Muslim must do totality in Da'wah to get Allah's blessing and favor. That is all we see the Islamic view on the secret of creation of the first mankind (Adam) on earth (Qur'an, 2: 30), as a Khalifah - the person who judges disputes that occur between people, forbidding them from injustice and sin, as Al- Qurtubi said - that Allah is the source of knowledge. Nobody knows the secret of creation, and not from His angels. The mankind - and also angels - has limit of knowledge, as He stated: "I know that which you do not know" (Qur'an, 2: 30). 
On the other side, the Qur'anic method of education comes from other approach when it talks about two most popular indulgences among the Arabs at the time, drinking and gambling (Qur'an, 2: 219). Sayyid Qutb (1966 C. E.) commented: "This statement is a good example of the judicious Qur'anic approach discernible in many Islamic legal and practical rulings and teachings. In addition, we often find that in matters of faith or abstract belief, Islam gives specific and definite pronouncements, but when it comes to matters of tradition or complex social practices, it takes a more pragmatic and measured approach, preparing the ground for smoother adoption and implementation".

In line with this discussion, Qur'an also emphasizes to the invitors in order to educate mankind with wisdom and fair preaching in their Da'wah activities as stated in the Sūrat alNahl: 125.

In conclusion, Islam as a cultural movement rejects strongly the old static view of the universe, and it encourages extremely a dynamic-holistic view. In its dynamic view, education must be seen as a fundamental unsure to achieve a great civilization, to be true Muslim, and to be Ummah Wasatan. It should be put into holistic view that the government, educational institutions, educators, students and all people, must do a good cooperation as a team-work in how to build a garden of knowledge and the virtue in educative environments which beneficial for Ummah.

\subsection{Rabbani Education In Dealing With the Problems}

Religion as interpreted by Western scholars is not same with the understanding of Muslim scholar. Religion in Muslim's view refers to the word "Dīn". The one word, Dinn has a grant of a privilege to the various meanings gathered in the unity of direction, al- Islām. It involves the owe condition, submission and surrender, the authority of punishment, evaluation and consideration, and the original character of humankind. Al-Islām has Dìn's principles as faith, belief, practice, education and guidance which will conduct its followers to the right way. Unfortunately, Majority of Indonesian Muslim pays no full attention to these principles. They neglect the main purpose of life, is 'Ibādah of Allah (51: 57). 'Ibādah is often translated into English as "worship", which is defined as honour and respect mixed with love and fear toward God, a god or a sacred object. 'Ibādah literally means subservience (i.e. the willingness to serve in a low position) as well as submission (i.e. the surrender of one's self or rights). Islamically 'Ibādah is to obey Allah by doing whatever He has commanded and by avoiding whatever He has forbidden. 'Ibādah involves serving God and surrendering (giving up) one's will to God's will. This is why the core of Islām is 'Ibādah, because the word Islām means the surrender of one's will to Allah, which is the highest level of obedience that one can reach. In other word, Dìn is a beauty city for Muslim, Islām is a peace inside it, and 'Ibādah becomes breath for each Muslim's life.

In relation of the nation's goals of education, religion (read: Dīn) plays an important role in building a great civilization. Islam enlightens about true and evil, like two sides, positive and negative, light and dark, soft and hard, clean and dirty, etc. God glorifies the man with a sacred superiority, 'Aql, to do his duty as a leader in the earth. The first thing that Allah showed to His servant (Adam) is teaching of the names. As we knew that our prophet (pbuh) in his first revelation was instructed to read what His angel (Jibrīl) required. This illustration indicates an importance and priority of learn and teach, or we called as education. Moreover Islām encourages each Muslim to learn and learn until the last breath (Hadīs). In short, the process of education must be guided by Islamic values and ethics. 
The virtue of moral in all of our movements is very important. We can't say no. The reality is our education system was broken by "the uncivilized actors" those who snuck in the circle of Islam as known as hypocrite people. They like to purchased badness by kindness, replace guidance to deviation. They have tarnished the truth by making education as land of capitalism. In this condition, ethic becomes more important to be highlighted, because it is related to the education affairs in shaping the characters.

In modern western civilization for example, we can see how it was built by materialistic, far removed from any spiritual or religious influence on the souls of individuals or societies. Religion continued to lose its influence over westerners, little by little, until westerners found themselves in this state of crisis and deep, overwhelming anxiety. Their thinkers and intellectuals now wish that they could make up for what they are lacking in spirituality, but how can they do that when the tree has already borne fruit and sent down deep roots ? [13].

On the other hand, the problem of Ummah is more complex. Economic, politic, social, culture, and religion are the hue of life which related each other. To achieve economic and technological advancement as well as social harmony, environmental sustainability, and basic happiness, we need to cultivate a pervasively influential national knowledge culture. Knowledge culture is not one that merely emphasizes on the love of knowledge and learning, and the mastery of the various sciences and skills, but one that also inculcates mature spirituality and ethical qualities actively, enabling our leaders and citizens to optimally realize our individual and collective potentials. The benefits reaped will not only be personal and national, but global as well. In this Information Age, the constant bombardment of facts, ideas, images and opinions from diverse - and often times conflicting - perspectives can be confusing and painful at a personal level, and may even be harmful to society. Hence, a permanently basic, coherent, and architectonic epistemological framework is thus needed for everyone in order to meaningfully select, interpret, and utilize information, ideas, and opinions from these various sources. The basic framework is provided permanently by a dynamic category of knowledge known as fardu al- 'Ain, which is obligatory to everyone, while all the others that are deemed necessary for societal advancement is fardu al- Kifāyah. The understanding and implementation of a dynamic form of fardu al- 'Ain and fardu al- Kifāyah knowledge and skills must be properly taught and disseminated. Dynamic fardu al- 'Ain knowledge should not stop at the basic knowledge of religion that can be mastered by the end of God and the development of character and propriety (Adab). This is the basis for Imam AlGhazzali's Tree of Governance, which questions the static understanding of the concept of fardu al- 'Ain, and which explains the increase in social problems, lack of integrity, white collar crimes, and extremism among those who are quite trained in basic religious knowledge and skills and who are experts in various fardu al- Kifāyah areas. In this context, the faulty understanding of the concept of fardu al- Kifāyah has compromised the fulfilling of social responsibility, which is expected in Islam, and has defined excellent achievement to the quantitative dimension only instead of the qualitative. The improvement of quality depends very much on a deep understanding of and sincere practices in the knowledge of fardu al- 'Ain [14].

The knowledge culture that is propagated by Islam and all major religions in the country aims to produce educated human beings who understand the limits of truth and usefulness of everything, and act accordingly [15].

Through the true Islamic worldview of knowledge with the cultivation of knowledge culture will guide us towards a balance of all aspects, social, economy, politic, which is absolutely determined by Ma'rifat Allah implied in the principles of al- Rubūbiyyah (the Lordship of Allah). This is that exist in Rabbānī education. 
Rabbani education is a way for the reconciliation. It is formulated in integrated system that all people must hold on its guideline. It works at the all levels, without dichotomy of knowledge. The Rabbāni education try to adopt Islamic values and commits to actualize that values in educating people, and always keep the continuity of universe in the harmony conducting. In another word, knowledge (al- 'Ilm) and implementation of worship (al- 'Amal) must walk together under God's Law (al- Syarı̄’ah al- Islāmiyyah). The urgency of integration of knowledge and action was stated clearly in the Qur'an (103: 3, and 18: 107, and 25: 70), where al- Imān (belief) means knowledge, and righteous deeds means real action. Imam alGhazāli said on his book:

"O Son! Knowledge without action is sheer folly, but there is no action without knowledge. Know that any type of learning that does not distance you from sins and brings you back to obedience today will never remove you from the fire of hell tomorrow. When you do not act today, nor right your actions of past days, you will say tomorrow, on the the Day of Resurrection: "Send us back to do good deeds", and you will be told: "Oh, fool ! You come now from there". And he also said: "The sum total of learning is to know the meaning of obedience and service (to God). While, al- Hasan al- Basri (God have mercy on him) said: "To know the true sense (of worship) is to stop thinking about the deed, but not to stop doing it" [16].

In connection with this ethic, Syed Muhammad Naquib al- Attas formulated the concept of Adab or how to put something in its proper place, there are eight important points [17]:

1) To put God in His proper place is to understand well His Attributes, Names, and Act, without having to know His innermost essence, and to practice His religion in the right way, and as exemplified by His Prophet; and to leave behind those that God has forbidden and to constantly improve oneself and ask for His forgiveness;

2) To put Prophet Muhammad (pbuh) in his proper place is to understand his most elevated stature, to follow his example without worshipping him, and to protect the rights of his companions and descendants;

3) To put leaders in their proper place is to think honorably of them and their families, to support their policies and to advise them, and not to bring them down because of their mistakes or errors, which may affect public interest and national stability. However, we are never to obey or aid them in unjust or sinful acts;

4) To put the people in their proper place is to be kind to them, to help them to achieve a decent and happy life by protecting their lives, dignity and security, as well as their religious , economics, and family rights;

5) To put Nature in its proper place is to recognize it as signs of God's knowledge, mercy, power, and wisdom, and to make use of it wisely and sustainably;

6) To put one's nation in its proper place is to understand its unique history and achievements, to defend its integrity and sovereignty, and advance its larger interests without oppressing or harming others;

7) To put knowledge in its proper place is to give due priority to fundamental religious knowledge and the humanities (fardu al- 'Ain) and to employ that to frame, develop, organize, and evaluate all the socially, economically, and technologically relevant knowledge and skill (fardu al- Kifāyah). In fact, the objective and methodology of acquiring knowledge as well as its academic value and benefits is seen from the worldview and framework of religious knowledge that is wide and all encompassing;

8) Putting scholars and specialists in their proper place is to give wide support and opportunities for them to enhance their expertise and to channel their views and experiences to the leadership and society without fear or favor. 


\section{CONCLUSION}

Development of science and technology has opened widely accessibility in information sector and digital system. It significantly has replaced the human roles and influenced our education system. In other side, religion in the modernization was separated from daily life by materialist community. It becomes propaganda in the brainwashing process by hypocrites. It seems like a contradictive condition between maturity of humankind and lack of humanistic values. Human development and values which focused on how to develop people's perception and understanding of moral values was colonized by the barren systems drive the people toward destruction for a while. Any programs of values education which engages only in analyzing one's thoughts without providing the means of action is clearly going to be limited in its impact. Therefore, to bridge the gap between the theory and practice, problem and solution, human and nature, we need an integrated, holistic and affective education system, is only pervaded by Rabbani education which has prudent approaches and noble goals in the civilization of humankind. Rabbani education is the solution for Ummah. It is a sturdy system which able to teach the people education values based on the Lord's principles and go forward in balance to develop Ummah Wasatan, the best nation or the real Islamic community.

\section{REFERENCES}

[1] The New Universal Library, The New Universal Library, Volume 7. London: The Caxton Publishing Company, 1968.

[2] al- Rāghib al- Asfahānī, Mufradat al- Fadzal-Qur'an. Damascus: Dar al- Qalam, 2009.

[3] Ibn Manzūr, Lisān al- 'Arab, Vol. 1. Beirut: Dār Sādir.

[4] Fakhr al- Dīn al- Rāzī, Mafātīh al-Ghayb, Vol. 8. Beirut: Dar al- Fikr, 1981.

[5] Ibn Kathīr, Tafsir Ibn Kathīr (Abridged by a group of scholars), 1st ed. Riyadh: Darussalam, 2000.

[6] Sayyid Qutb, In the Shade of the Quran, 1st ed. London.

[7] Pimpinan Pusat Muhammadiyah, Anggaran Dasar dan Anggaran Rumah Tangga Muhammadiyah, 1st ed. Yogyakarta: Suara Muhammadiyah, 2005.

[8] A. N. Burhani, "Pluralism, liberalism and islamism: Religious outlook of Muhammadiyah," Stud. Islam., vol. 25, no. 3, pp. 433-470, 2018.

[9] A. A. B. Philips, Islamic Studies (Book 1), 1st ed. Kuala Lumpur: A. S. Noordeen, 2004.

[10] Suhariyanto, "BPS: Poverty Rate in Indonesia Decreases," 2019. [Online]. Available: https://setkab.go.id/en/2019/01/page/9/. [Accessed: 25-Jul-2019].

[11] C. C. Manan, "Indonesia GDP Annual Growth Rate," 2019. [Online]. Available: https://tradingeconomics.com/indonesia/gdp-growth-annual. [Accessed: 26-Jul-2019].

[12] R. A. Chaves, "Indonesia Maintains Steady Economic Growth in 2019," 2019. [Online]. Available: https://www.worldbank.org/en/news/press-release/2019/07/01/indonesia-maintainssteady-economic-growth-in-2019.print\%0A.

[13] Mustafa al- Siba'ie, Civilization of Faith (A Journey through Islamic History). Riyadh: International Islamic Publishing House, 2005.

[14] Wan Mohd Nor Wan Daud, The Educational Philosophy and Practice of Syed Muhammad Naquib al- Attas. Kuala Lumpur: ISTAC, 1998.

[15] S. M. N. Al-Attas, Prolegomena To the Metaphysics of Islam. Kuala Lumpur: ISTAC, 1995.

[16] al- Ghazali, Classical Foundation of Islamic Education Thought (O Son!). 2010.

[17] Wan Mohd Nor Wan Daud, Knowledge Culture and The Concept of 1 Malaysia (Building A Developed and Happy Nation), 1st ed. Kuala Lumpur: Akademi Kenegaraan BTN, Jabatan Perdana Menteri, 2012. 